\title{
Peripheral Blood Smear Findings in COVID-19
}

\author{
COVID-19 Hastalarında Periferik Yayma Bulguları
}

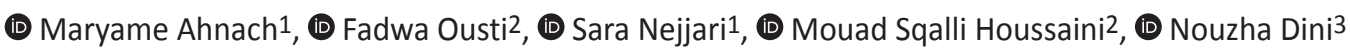

\begin{abstract}
${ }^{1}$ Cheikh Khalifa International University Hospital, Mohammed VI University of Health Sciences, Department of Hematology, Casablanca, Morocco

2 Mohammed VI University of Health Sciences, National Reference Laboratory, Casablanca, Morocco

${ }^{3}$ Mohammed VI University of Health Sciences, Cheikh Khalifa International University Hospital, Casablanca, Morocco
\end{abstract}

\section{To the Editor,}

In December 2019, coronavirus disease 2019 (COVID-19) emerged in Wuhan, China, and caused a global pandemic. The disease has a systemic manifestation including the hematopoietic system. It is clear that the hematologic laboratory will play an essential role in this crisis, contributing to patient screening, diagnosis, and prognosis. To date, complete blood counts (CBCs) have been recommended as useful tools for patient monitoring. Quantitative hematologic abnormalities have been reported since the first published papers and all blood cells can be affected during COVID-19, mainly leukocytes and platelets [1]. Blood smears are not performed systematically, but due to the presence of quantitative anomalies, a qualitative evaluation is useful for analyzing morphological changes during COVID-19.

In Morocco, with a record of 6741 confirmed cases and 192 deaths, the situation is less critical than in Europe and the United States [2]. A COVID unit was created in our hospital to provide assistance and care to patients from the Casablanca region. We have had up to 146 patients with COVID-19 as of May 16, 2020. The CBC parameters of our patient $(n=146)$ showed neutropenia (7.5\%), hyperleukocytosis (8\%), eosinopenia (47\%), monocytosis $(9.5 \%)$, Iymphopenia (46\%), and thrombopenia (10\%). We evaluated 15 first peripheral blood smears at admission and we found morphological abnormalities concerning leukocyte and platelet lineages. By observing blood smears colored by May-Grunwald-Giemsa stain, we noted the characteristics of a neutrophil granulocyte with dysmorphic morphology marked by hypogranular cytoplasm and hyposegmented nucleus. We observed the presence of atypical eosinophils containing multiple vacuoles. Rare activated lymphocytes and large monocytes were found in some peripheral blood films. Platelet morphology also showed frequent anomalies, mainly consisting of giant platelets with different sizes (Figure 1).

Very few articles have been published on blood morphology during COVID-19 infection. Two recent publications described the blood smears of infected patients, where the morphology of the neutrophil and platelet lineages showed very frequent anomalies in terms of nuclear morphology, cytoplasmic granulation, and the presence of atypical and immature cells $[3,4]$. Like most viruses that impact hematopoiesis and the immune system during developmental stages [5], COVID-19 causes blood cells to change by inflammatory mechanisms and the perturbation of the myelopoiesis system [6]. Moreover, it appears to have more serious effects, with deep cytopenia predictive of the severity [7]. CBCs completed with peripheral blood smears can detect the impact of the virus on the blood, reflecting early inflammatory signs.

Our preliminary results remain limited and more investigation is required to study the reversibility of these abnormalities and their impact on severity. Compared to all inflammatory biomarkers, observation of blood cells can be a simple alternative for the first triage and early identification of the infection.

Keywords: COVID-19, Morphology cells, Blood smears

Anahtar Sözcükler: COVID-19, Hücre morfolojisi, Kan yayması

\section{Ethics}

Ethics Committee Approval: Our study was supported with the approval of the Academic Ethics Committee of Mohammed VI University.

Informed Consent: Informed consent was obtained from the patients included in the study.

\section{Authorship Contributions}

Concept and Design: M.A.; Data Collection or Processing: S.N., M.S.H., N.D.; Literature Search and Interpretation: M.A., F.O.; Writing: M.A.

Conflict of Interest: None declared.

\section{Acknowledgments}

We thank Chafik El Kettani for his assistance and care of the infected patients and the National Reference Laboratory of Cheikh Khalifa International University Hospital for participation. 


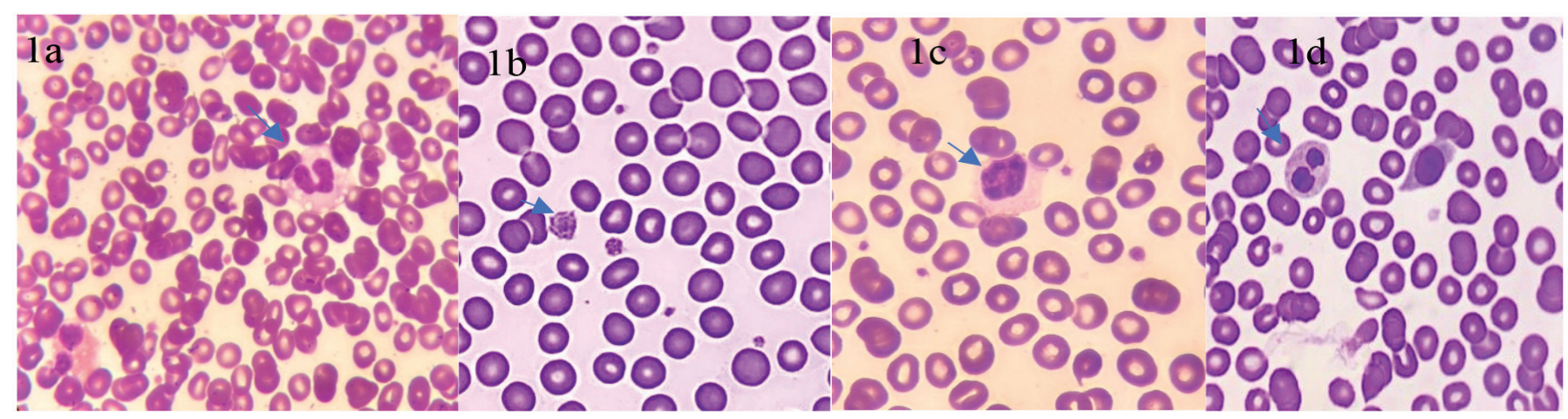

Figure 1. Blood smears of patients with COVID-19 (May-Grunwald-Giemsa): a) eosinophil containing multiple vacuoles; b) giant platelets with different sizes; c) circulation of a large lymphocyte; d) neutrophil granulocyte with marked hypogranular cytoplasm and hyposegmented nucleus.

\section{References}

1. Fan BE, Chong VCL, Chan SSW, Lim GH, Lim KGE, Tan GB, Mucheli SS, Kuperan $\mathrm{P}$, Ong KH. Hematologic parameters in patients with COVID-19 infection. Am J Hematol 2020;95:E131-E134.

2. Health Minister of Morocco. Coronavirus Disease COVID-19: Situation Report. Rabat, Health Ministry of Morocco, 2020. Available at http://www. covidmaroc.ma/pages/Accueil.aspx.

3. Zini G, Bellesi S, Ramundo F, d'Onofrio G. Morphological anomalies of circulating blood cells in COVID-19. Am J Hematol 2020;95:870-872.

4. Mitra A, Dwyre DM, Schivo M, Thompson GR 3rd, Cohen SH, Ku N, Graff JP. Leukoerythroblastic reaction in a patient with COVID-19 infection. Am J Hematol 2020;95:999-1000.
5. Pascutti MF, Erkelens MN, Nolte MA. Impact of viral infections on hematopoiesis: from beneficial to detrimental effects on bone marrow output. Front Immunol 2016;7:364.

6. Mehta P, McAuley DF, Brown M, Sanchez E, Tattersall RS, Manson JJ; HLH Across Speciality Collaboration, UK. COVID-19: Consider cytokine storm syndromes and immunosuppression. Lancet 2020;395:1033-1034.

7. Tan L, Wang $\mathrm{Q}$, Zhang $\mathrm{D}$, Ding J, Huang $\mathrm{Q}$, Tang $Y \mathrm{Q}$, Wang $\mathrm{Q}$, Miao $\mathrm{H}$. Lymphopenia predicts disease severity of COVID-19: a descriptive and predictive study. Signal Transduct Target Ther 2020;5:33.

\section{Hydroxychloroquine-Associated Thrombotic Thrombocytopenic Purpura}

\section{Hidroksiklorokin Ilişklili Trombotik Trombositopenik Purpura}

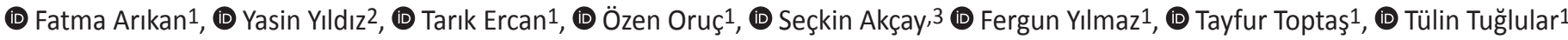

${ }^{1}$ Marmara University Faculty of Medicine, Department of Hematology, Istanbul, Turkey

2 Marmara University Hospital, Clinic of Internal Medicine, İstanbul, Turkey

3Ümraniye Training and Research Hospital, Clinic of Endocrinology, İstanbul, Turkey

\section{To the Editor,}

Although there have been inconsistent publications on the activity and safety of hydroxychloroquine $(\mathrm{HO})$, it is recommended by several treatment guidelines to be used for all patients with symptomatic COVID-19 disease. There were several concerns regarding the treatment-related side effects.
The most important side effects include OT prolongation and visual-field defects.

A 65-year-old man with chronic obstructive pulmonary disease was admitted to the hospital with the complaints of cough and chest and back pain. Physical examination was unremarkable. Computerized tomography and angiography of the chest 